\title{
Cambrian Bradoriida and Phosphatocopida (Arthropoda) of the former Soviet Union
}

\author{
LUDMILA M. MELNIKOVA ${ }^{1}$, DAVID J. SIVETER ${ }^{2}$ \& MARK WILLIAMS ${ }^{2,3}$ \\ ${ }^{1}$ Palaeontological Institute, Russian Academy of Sciences, Moscow, Russia. \\ ${ }^{2}$ Department of Geology, University of Leicester, Leicester LE1 7RH, UK. \\ ${ }^{3}$ Present address: British Geological Survey, Keyworth, Nottingham NG12 5GG, UK.
}

\begin{abstract}
Some 40 bradoriid and phosphatocopid (Arthropoda) species are known from the Cambrian of the former Soviet Union. The faunas occur chiefly in Asia (mostly Siberia and Kazakhstan; also Kirghizia); west of the Urals bradoriid and phosphatocopid faunas are sparse, occurring in the Leningrad region, Belarus and Estonia. Most specimens are recovered as crack-out material from clastic and impure carbonate rocks; acid resistant valves from limestones are a minor component of the known faunas.

Early Cambrian (Atdabanian-Botomian) faunas are widespread; middle and late Cambrian faunas are scarcer and are known largely from Siberia and Kazakhstan. Though many species are seemingly shortranging, currently most have only local biostratigraphic significance, with only a few having practical international correlative value.

Palaeogeographically, faunas west of the Urals show affinites with those of the Early Palaeozoic Baltica and Avalonia palaeocontinents (Olenellid trilobite realm). Siberian and central Asian (Kazakhstan, Kirghizia, Gorny-Altay-Mongolian belt) faunas show clear affinities with those of palaeocontinental South China and eastern Gondwana (Redlichiid trilobite realm). J. Micropalaeontol. 16(2): 179-191, October 1997
\end{abstract}

\section{INTRODUCTION}

Bradoriids and phosphatocopids are small, bivalved, almost exclusively Cambrian arthropods which first appear coevally with, or slightly later than the first trilobites (see Siveter $e t$ al., 1996 and references therein). In spite of the fact that from the early Cambrian onwards bradoriids and phosphatocopids have worldwide distribution and that they often form abundant elements of Cambrian faunas (e.g. Hou \& Bergström, 1991), their use in biostratigraphy and biogeography has largely been neglected. Several recent studies have highlighted their widespread occurrence in the Cambrian of especially Britain (see Siveter \& Williams, 1995; Rushton et al., in press; Williams \& Siveter, in press), North America (see Siveter \& Williams, 1977), Australia (Jones \& McKenzie, 1980; Hinz-Schallreuter, 1993a), the Baltic (Hinz-Schallreuter, 1993b, 1993c) and China (see Shu, 1990a, 1990b with nomenclatorial annotations by Malz, 1990; Huo et al., 1991 and references therein) and have demonstrated their biogeographical and regional and international correlative potential (e.g. Siveter et al., 1993; Williams et al., 1994b; Siveter \& Williams, 1995). Bradoriids and phosphatocopids are also known from several parts of the former Soviet Union but a comprehensive account of their geographical occurrence and their biostratigraphic and biogeographic distribution and value remains to be elucidated; these are the primary aims of our paper.

Most of the some 40 bradoriid and phosphatocopid species known from the former Soviet Union are from central and eastern Asia (Fig. 1). Many species were collected as part of geological field reconnaisance studies and are known from only a few specimens; thus, information regarding exact geographic and stratigraphic provenence is sometimes imprecise. As far as the material at our disposal allows we have, where appropriate, revised the generic assignment of all of the bradoriid and phosphatocopid species of the former Soviet Union.

Small bivalved arthropods of the Cambrian have traditionally been referred to the Order Bradoriida Raymond, 1935 and considered to include the oldest representatives of the ostracod crustaceans (Müller, 1964, 1979; Jones \& McKenzie, 1980). Both major groups of bradoriids, the Bradoriina Raymond, 1935 and the Phosphatocopina Müller, 1964, were raised to ordinal level in Müller, 1982 (adopted herein). Because of the problem of convergent evolution, resulting in the possession of a bivalved shell in many otherwise disparate groups of arthropods (as in ostracods, phyllocarids and some Burgess Shale taxa), recognition of the true affinities of such fossil forms ultimately depends on the preservation of appropriate soft parts (e.g. see Briggs, 1983; Müller \& Walossek, 1991), rare examples of which are now known from both phosphatocopids and bradoriids (e.g. Müller 1979, 1982; Hou et al., 1996). Thus, some authors now consider the Phosphatocopida to be merely stem-group Crustacea (Müller \& Walossek, 1991; Walossek \& Müller, 1992; but see also, for example, Hinz-Schallreuter, 1993b, 1993c), and the Bradoriida are regarded as merely a polyphyletic grouping of perhaps several arthropod groups which questionably includes some ancestral ostracods (e.g. Jones \& McKenzie, 1980; Siveter et al., 1996; Hou et al., 1996).

Most of the phosphatocopid and bradoriid specimens from the former Soviet Union are preserved on rock slabs, as partly flattened valves and carapaces. Some secondarily(?) phosphatized specimens have been extracted from limestones from Siberia (Müller et al., 1995) and Kazakhstan (Melnikova \& Taylor, unpublished). This material is the sort of provenance (see Müller, 1979) which might yield phosphatocopids or bradoriids with soft tissues preserved.

\section{HISTORY OF RESEARCH AND GEOGRAPHICAL DISTRIBUTION}

The earliest documentation of bradoriids and phosphatocopids are based on mid- to late 19th Century studies of British and North American faunas (see Rushton et al., in press; Siveter \& Williams, 1997; Williams \& Siveter, in press). In contrast, these groups were only quite recently recorded from the former Soviet Union, as a result of field and faunal studies in the Cambrian of Asia (Figs 1,2). From the 1950s onwards finds were made in 


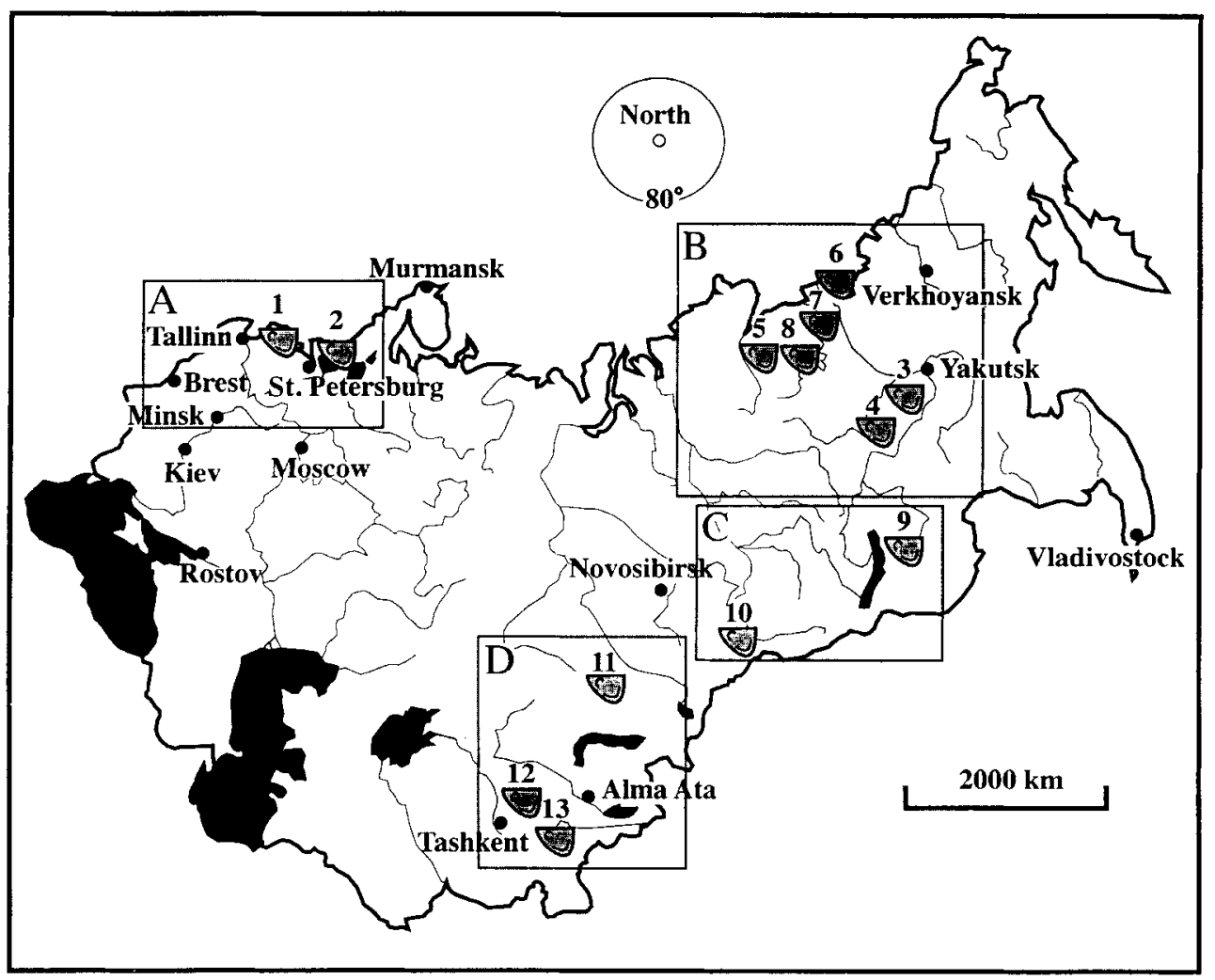

Fig. 1. Geographic distribution of Cambrian bradoriid and phosphatocopid faunas of the former Soviet Union (grey icon): A, Baltic (Estonia-western Russia) faunas; B, Siberian faunas; C, Gorny Altay-Mongolian belt faunas; D, central Asian (Kazakstan-Kirghizia) faunas (see Fig. 2). Unstudied material is known from a borehole near Brest, Belarus. Numbers $1-13$ refer to individual areas given in Fig. 2.

Siberia by palaeontologists such as N. P. Suvorova, V. Ye. Savitskii, N. P. Lazarenko, L. N. Repina and E. B. Romanenko. The earliest formal descriptions were of Siberian material from early Cambrian Atdabanian limestones of the Lena-Aldan region (Cambria sibirica Neckaja \& Ivanova, 1956) and near Chekurovka in the Khara-Ulakh Mountains (Cambria melnikovi Ivanova, 1964) and of Anabarochilina Abushik, 1960 and 'Leperditia' from the early late Cambrian of the Kotui River area (Abushik, 1960). Melnikova (1983a, 1983b) documented additional taxa from Siberia.

Later, material was recorded from non-Siberian parts of the former Soviet Union. The middle Asian regions of Kazakhstan, Kirghizia and the Gorny Altay-Mongolian belt have all yielded Cambrian bradoriids and/or phosphatocopids, including the types of Ushkarella Koneva, 1978, Tscholponaella Melnikova, 1990, Uskutchiella Melnikova, 1992 and Altajanella Melnikova, 1992 (Koneva, 1978; Melnikova, 1988, 1990a, 1990b, 1992). In contrast, bradoriids and phosphatocopids have been noted only rarely in that part of the former Soviet Union west of the Urals. A few species occur in the Baltic state of Estonia and in the Leningrad region (Melnikova, 1984, 1985, 1987). Unpublished faunas are also known from borehole material from western Belarus.

Most recent studies have either been short general summaries about the bradoriids and phosphatocopids of the former Soviet Union (Melnikova, 1990c, 1990d) or detailed revisions of
Siberian species which, in some cases, identify widespread biostratigraphical potential (e.g. Siveter et al., 1993, 1994, 1996; Hinz-Schallreuter, 1993c; Williams et al., 1994a). The possibility of obtaining additional bradoriid and phosphatocopid material from the former Soviet Union is particularly well demonstrated by the acid-resistant faunas obtained from limestones in Siberia (Müller et al., 1995) and from Kazakhstan during the 1980s by Melnikova and Taylor (unpublished manuscript; see herein Pls $3,4)$.

\section{BIOSTRATIGRAPHIC DISTRIBUTION}

In the former Soviet Union bradoriids and phosphatocopids occur throughout the Cambrian but are known chiefly from the early parts of the system (Fig. 2). Many species are shortranging (Fig. 3), but currently most have only local biostratigraphic significance, with only a few having practical international correlative value.

The Cambrian stratigraphy (Fig. 2) of the southern slope of the Baltic Shield and of Siberia is outlined in Mens et al. (1990), Cowie (1989) and Astashkin et al. (1991). The overall Cambrian stratigraphy in Kazakhstan and Kirghizia is currently under study, but some sequences are documented (e.g. Mambetov \& Repina, 1979; Ergaliev, 1980; Brasier, 1989; Melnikova \& Taylor unpuplished manuscript). The Cambrian stratigraphy of the Gorny Altay-Eastern trans-Baikal regions of Asia is discussed in Astashkin et al. (1995). 


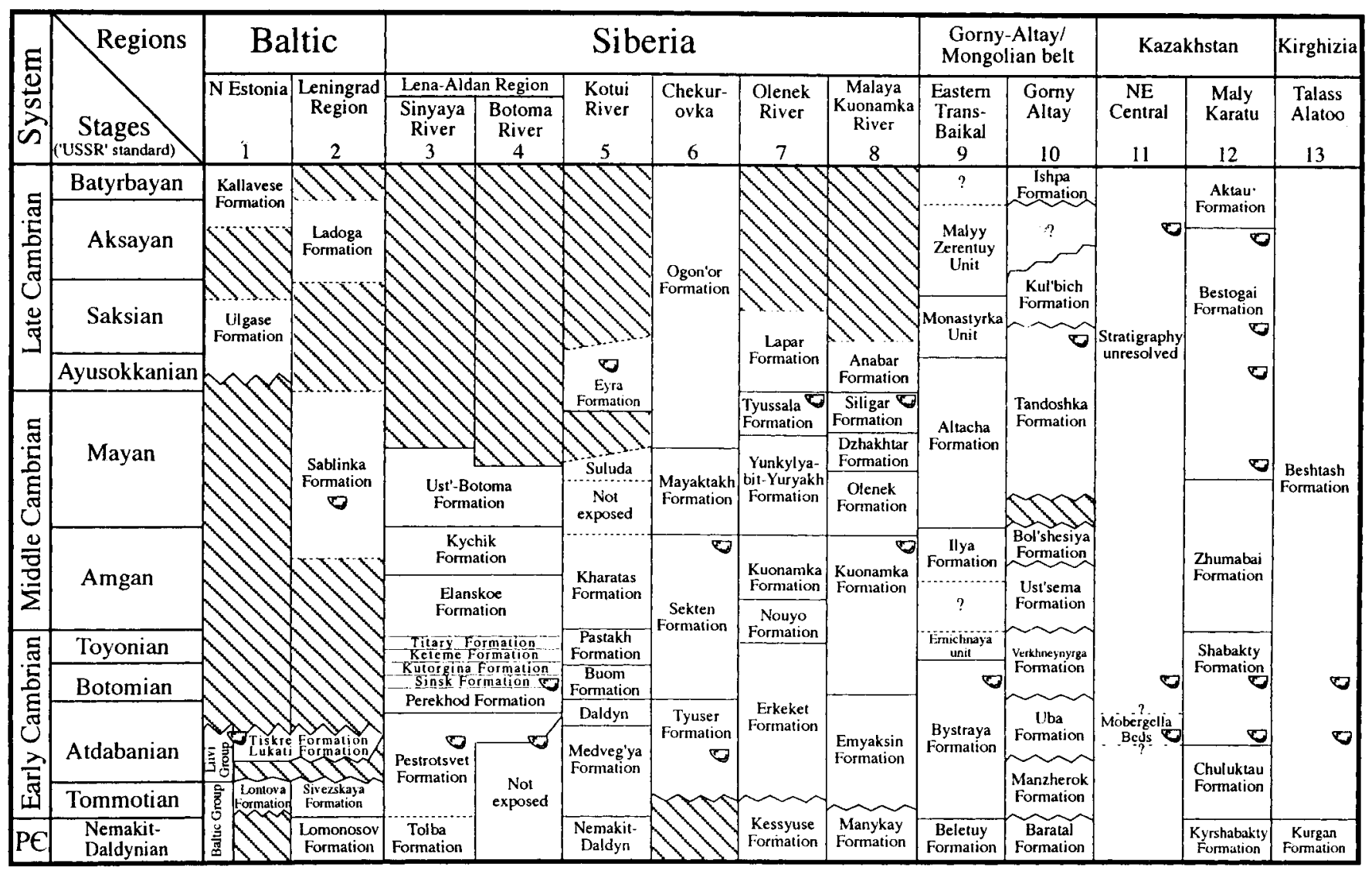

Fig. 2. General stratigraphic distribution of bradoriid and phosphatocopid faunas of the former Soviet Union (indicated by the icon). For References relating to the stratigraphy see text. The Precambrian-Cambrian boundary is drawn as in Astashkin et al. (1991, 1995).

\section{Early Cambrian (Pls 1, 2)}

Most early Cambrian species are restricted to either the Atdabanian or Botomian stages. The oldest, Atdabanian faunas occur in East Siberia (see Figs 1-3) and are characterized by cambriid bradoriids. These include Cambria melnikovi $(=$ Cambria melnikovae in error in Siveter et al., 1994) from the Tyuser Formation near Chekurovka village and Cambria sibirica and Cambria egorovae Melnikova, 1983 from the Lena-Aldan Region (Neckaja \& Ivanova, 1956; Ivanova, 1964; Melnikova, 1983a; see also Siveter et al., 1994; Williams et al., 1994a). The lithostratigraphic provenance for the latter two species is less precise, though they may be from the Pestrotsvet Formation (see Fig. 2), which has subsequently yielded other possible cambriids. Cambriids are amongst the oldest bradoriids, characterising approximately coeval rocks in Russia, South China (Qiongzhusi Stage, Atdabanian) and North Greenland (Nevadella - Bonnial Olenellus trilobite Biozones; Siveter et al., 1996). Some of these cambriids may be congeneric or even conspecific, but renewed collection of the Siberian and Chinese taxa is necessary in order to test this and their true correlative value (see also Siveter et al., 1996).

In northern Estonia middle Atdabanian phosphatic sandstones of the Tiskre Formation yield Konicekion kundaensis Melnikova, 1987 and Bradoria (= gen. nov.?) estonica Melnikova, 1987. Neither species is known from other Baltic Cambrian faunas (e.g. Wiman, 1905; Hinz-Schallreuter, 1993c).

The Mobergella Beds of Atdabanian age in central Kazakhstan has the bradoriids Houlongdongella sp. (= Alutella sp.), Bradoria sp. 1 (= cambriid? gen. et sp. nov.) and Tsunyiella gridinae Melnikova (1990a). This assemblage is similar to bradoriid faunas from the early Cambrian of China (see Zhang, 1987; Huo \& Cui, 1989; Huo et al., 1991), where species of Tsunyiella Zhang, 1974 have been used as indices for the early Cambrian Qiongzhusi and Canglangpu stages (see Huo \& Cui, 1989, table 1).

Botomian faunas of Siberia include Bradoria (= gen. nov?) ordinata Melnikova, 1983a, from the Bergeroniellus guarii Biozone of the Sinsk Formation of the Lena-Aldan Region, and Sunella (=gen. nov.?) parva Melnikova, 1988, Liangshanella? sayutinae (Melnikova, 1988) and Alutella usloniensis (Melnikova, 1988) from the Bystraya Formation of the Eastern Trans-Baikal region. In China species of Liangshanella Huo, 1956 and Alutella Kobayashi \& Kato, 1951 also typify the early Cambrian Qiongzhusi and Canglangpu stages (Hou Xianguang, personal commun., November 1995; see also Huo et al., 1991). Dabashanella retroswinga Huo, Shu \& Fu (in Huo et al., 1983), also a widespread species in the Qiongzhusi Stage (see Zhao \& Tong, 1989; Huo et al., 1991), occurs in the Shabakty Formation of Kazakhstan (in association with the hyolith Microcornus parvulus) and the Beshtash Formation of Kirghizia (in associa- 


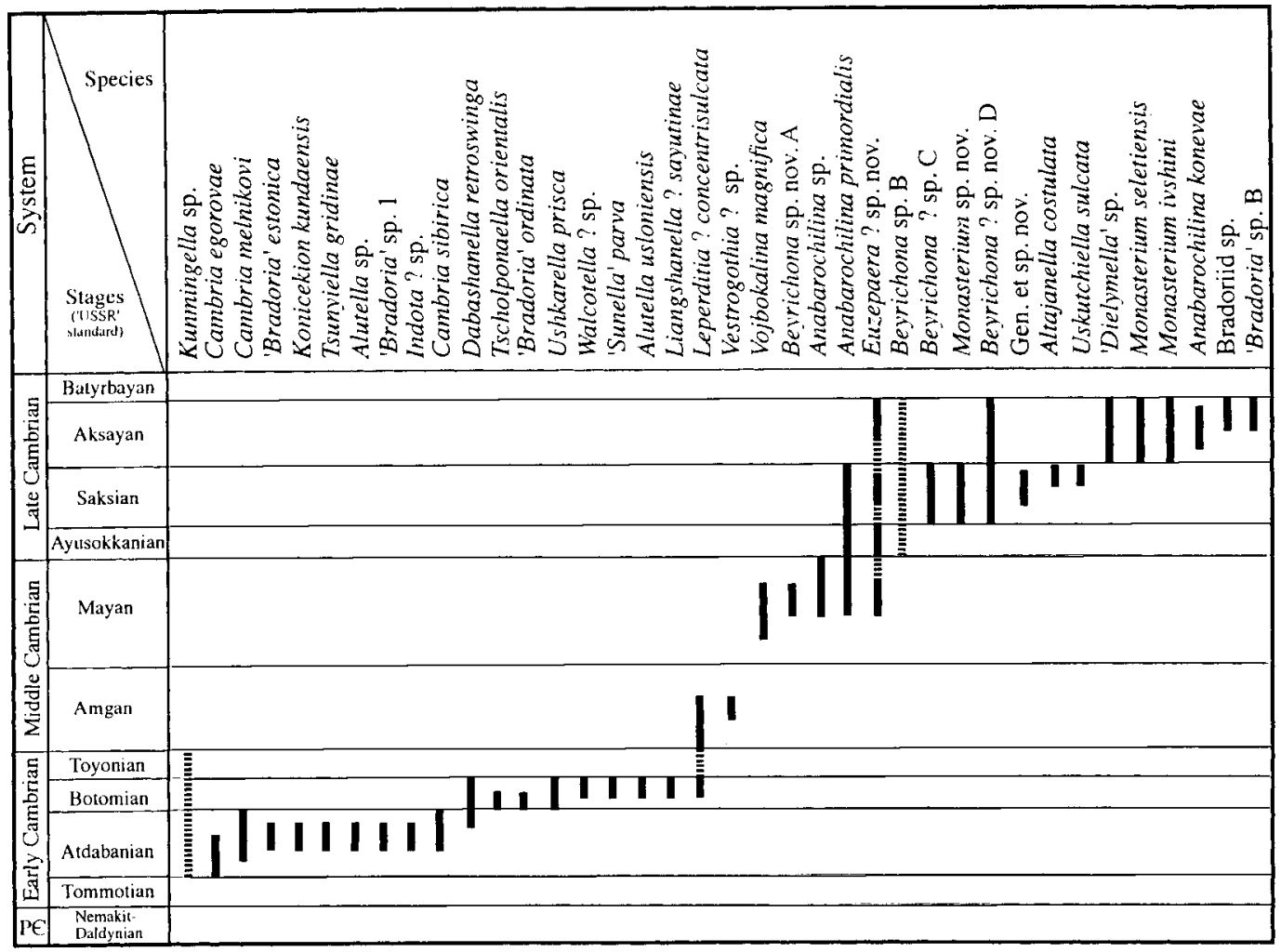

Fig. 3. Biostratigraphic distribution of bradoriids and phosphatocopids of the former Soviet Union. Broken lines denote an uncertain stratigraphic range. The Precambrian Cambrian boundary is drawn as in Astashkin et al. (1991, 1995).

tion with $M$. parvulus and Rhombocorniculum cancellatum; Melnikova, 1990b). Indigenous Botomian taxa in former Soviet middle Asia include Ushkarella prisca Koneva, 1978 from the Edrei beds of central Kazakhstan and Tscholponaella orientalis Melnikova, 1990 from the $M$. parvulus Biozone of the Beshtash Formation of Kirghizia.

The Siberian species Leperditia? (= gen. nov.) concentrisulcata Abushik, 1960 ranges from the early Cambrian Botomian of the
Lena-Aldan Region into the middle Cambrian (Amgan Stage) Kuonamka Formation of the Malaya Kuonamka River Region.

Collections in the Palaeontological Institute, Moscow, include Kunmingella Huo, 1956 from an unspecificed, presumed early Cambrian locality in Siberia (P1. 2, fig. 6). The latter genus characterizes the early Cambrian, especially the Qiongzhusi Stage, of China (Shu, 1990b; Huo et al., 1983, 1991).

\section{Explanation of Plate}

Early Cambrian bradoriids/phosphatocopids of the former Soviet Union. fig. 1 is a dorsal view; all others are lateral views. figs 3, 7, 9, 10 are scanning electron micrographs; all other figures are light photographs (methods of Siveter, 1990). fig. 1, Atdabanian, right side of the Lena River, $5.5 \mathrm{~km}$ from the mouth of the Anna-yuriiete River, Siberia. figs 2, 5, 6, 11, Mobergella Beds (Atdabanian), left bank of the Selety River, $9 \mathrm{~km} S$ of Bestyube, N Central Kazakhstan. fig. 3, Beshtash Formation (Botomian; Microcornus parvulus Biozone), left bank of the Beshtash River, $1.8 \mathrm{~km}$ NE of the mouth of Kaindy Stream, Kirghizia. fig. 4, Tyuser Formation (Atdabanian), left bank of the Lena River, $4 \mathrm{~km} \mathrm{~S} \mathrm{of} \mathrm{Chekurovka,} \mathrm{Khara-Ulakh} \mathrm{Mountains,}$ Siberia. fig. 7, Tiskre Formation (Atdabanian), Dominopolskii Horizon, Kunda Quarry, N Estonia. fig. 8, Adtabanian, left bank of the Botoma River, $4 \mathrm{~km}$ from the mouth of the Khara-Uryach River, Siberia. fig. 9, Shabakty Formation (Atdabanian), Berkuty River, Maly Karatau, S Kazakhstan. fig. 10, Tiskre Formation (Atdabanian), Dominopolskii Horizon, Koze-Lyukati outcrop, N Estonia. fig. 1. Cambria egorovae Melnikova, 1983. Holotype, carapace, PIN N3465/10, length $5.81 \mathrm{~mm}$. fig. 2. Tsunyiella gridinae Melnikova, 1990, Paratype, left valve (stereo-pair), PIN N4343/12, length $6.67 \mathrm{~mm}$. fig. 3. Tscholponaella orientalis Melnikova, 1990. Holotype, carapace, PIN N4344/1, left lateral view (stereo-pair), length $0.94 \mathrm{~mm}$. fig. 4. Cambria melnikovi V. Ivanova, 1964. Holotype, left valve, PIN N2175/1, length $6.43 \mathrm{~mm}$ (measurement revised from Siveter et al., 1994). fig. 5. Bradoria sp. 1 of Melnikova, 1990 (=cambriid? gen, et sp. nov.). Right valve, PIN N4343/13, length 4.91 mm. fig. 6. Alutella sp. (= Houlongdongella sp. of Melnikova, 1990). Left valve, PIN N4343/9, length $3.57 \mathrm{~mm}$. fig. 7. Konicekion kundaensis Melnikova, 1987. Holotype, right? valve (stereo-pair), PIN N4341/30, length $1.19 \mathrm{~mm}$. fig. 8. Cambria sibirica Neckaja \& V. Ivanova, 1956. Holotype, left valve, PIN N117/2, length $5.71 \mathrm{~mm}$ (measurement revised from Williams et al., 1994a). fig. 9. Dabashanella retroswinga Huo, Shu \& Fu, 1983. Carapace, PIN N4343/35, left lateral view, length $1 \mathrm{~mm}$. fig. 10. Bradoria estonica Melnikova, 1987 (= gen. nov.?). Holotype, carapace, PIN N4341/31, left lateral view, length $1.33 \mathrm{~mm}$. fig. 11. Indota? sp. Right valve, PIN N4343/98, length $1 \mathrm{~cm}$. 


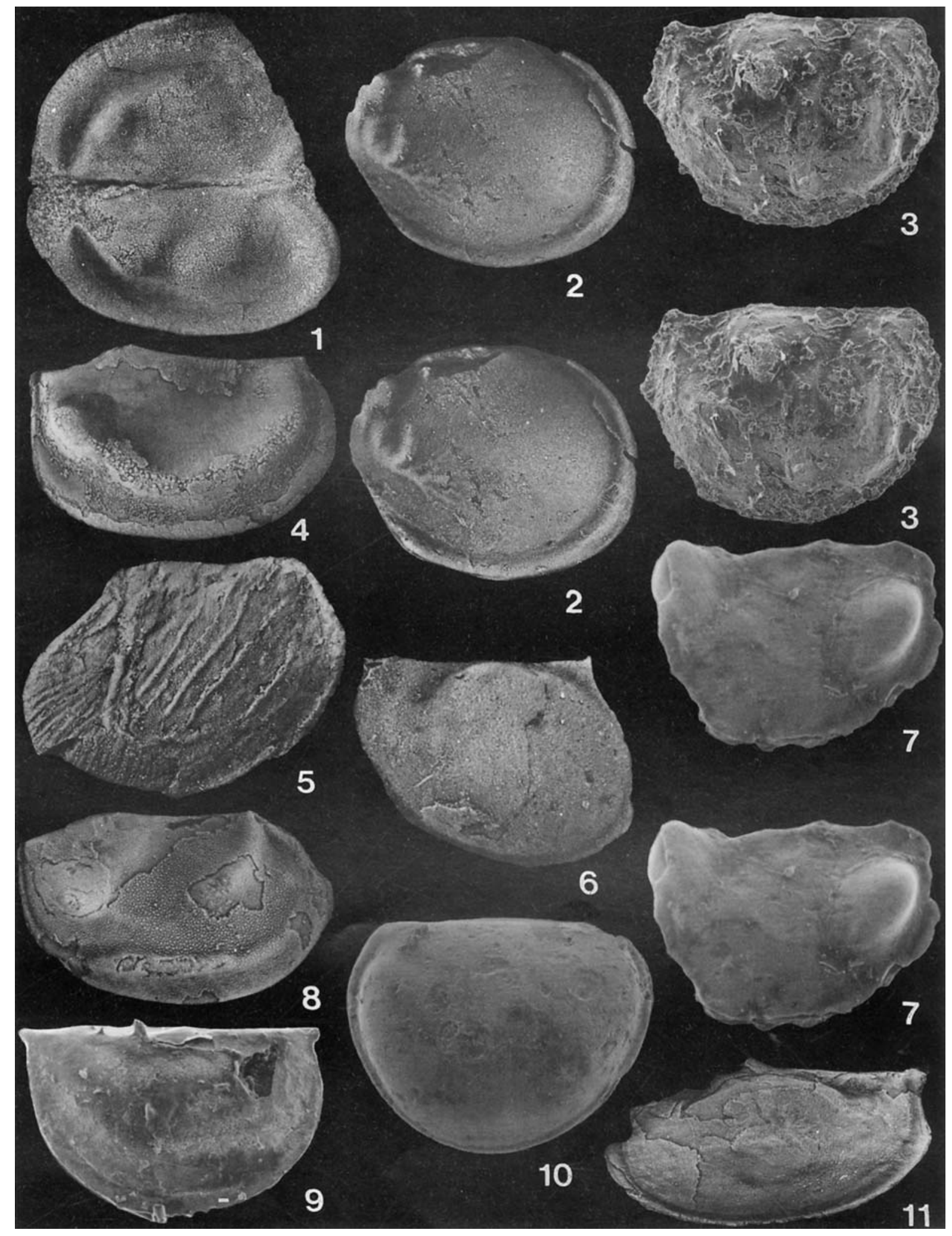




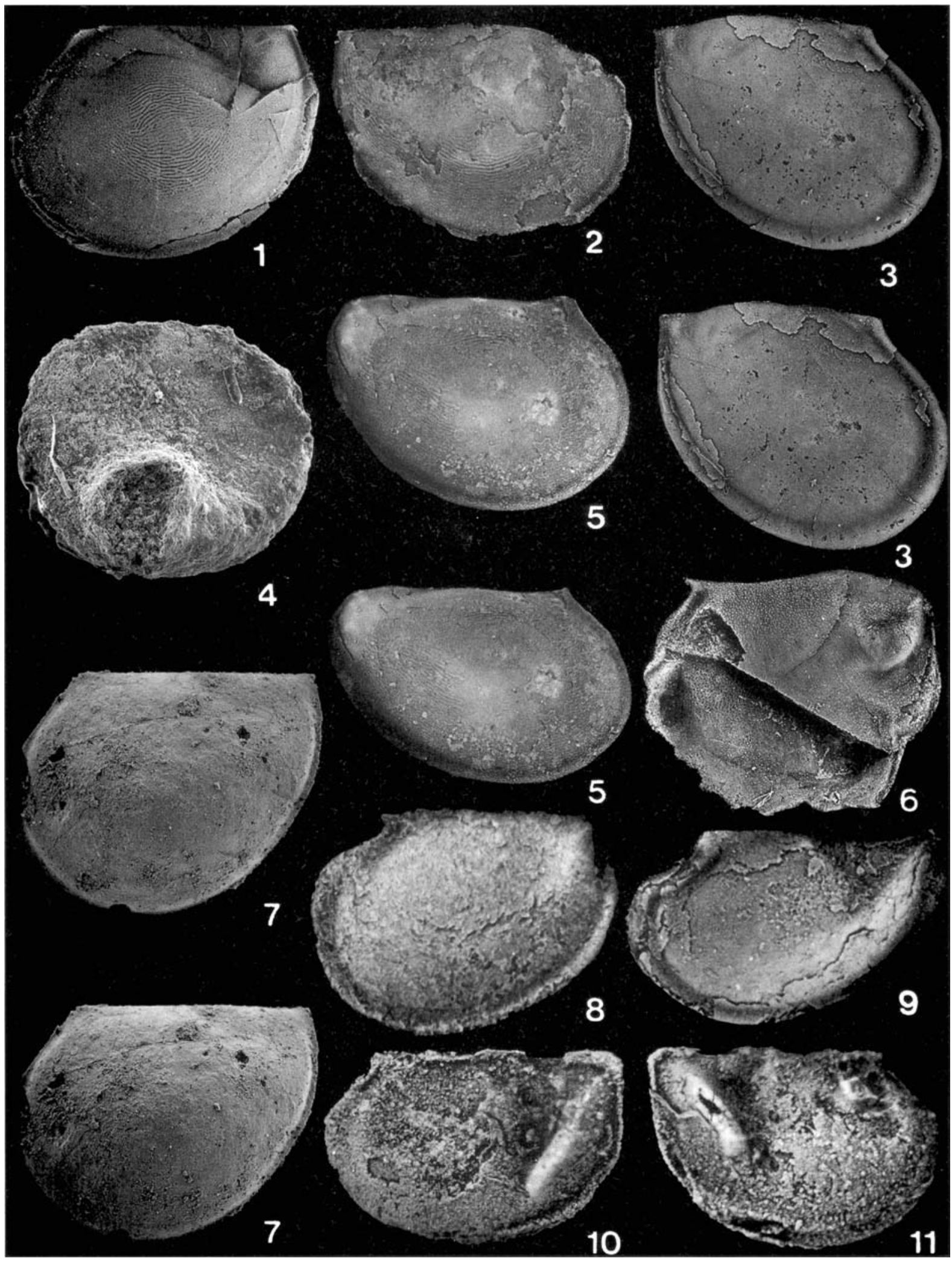




\section{Middle Cambrian (Pls 2, 3)}

Middle Cambrian bradoriid and/or phosphatocopid faunas contain relatively few taxa and are more sparsely distributed and often stratigraphically and geographically more imprecisely defined than the early Cambrian assemblages (Figs 2, 3). Anabarochilina primordialis (Linnarsson, 1869) is known from the late middle and late Cambrian of Siberia and the middle Cambrian of southern Britain and Scandinavia (see Siveter et $a l$., 1993). Verification of its full correlative value awaits systematic recollection of Siberian material. A. primordialis occurs in the late Cambrian Eyra Formation of the Kotui River region and probably occurs in the middle Cambrian Siligar Formation of the Malaya Kuonamka River region (Fig. 2). The record of $A$. primordialis from the late Cambrian dolomites of the Lapar Formation of the Olenek River region may be in error; more likely it is from limestones of the middle Cambrian Tyussala Formation (see also Melnikova, 1984; Abushik, 1960; herein Fig. 2). The only other named middle Cambrian taxon from Siberia is Vestrogothia? sp., represented by a single specimen from the Amgan Stage Sekten Formation near Chekurovka in the Khara-Ulakh Mountains (Pl. 3, fig. 10); additional finds comprise indeterminate phosphatocopids from the Kuonamka Formation (Müller et al., 1995).

Several new species are known from the middle Cambrian of southern Kazakhstan (Melnikova \& Taylor manuscript; herein Pl. 3, figs 1, 5, 9). They include a late middle Cambrian (Lejopyge trilobite Biozone) Anabarochilna species, which resembles the middle Cambrian Anabarochilina australis (HinzSchallreuter, 1993c) from Australia, and a middle to late Cambrian form probably referable to the typically late Cambrian Chinese genus Euzepaera Shu (see Shu, 1990a).

West of the Urals the only known middle Cambrian species is Vojbokalina magnifica Melnikova, 1984, from the Sablinka Formation of the Leningrad Region.

\section{Late Cambrian (Pls 3, 4)}

Possible late Cambrian bradoriid and/or phosphatocopid faunas from west of the Urals are known only from as yet unstudied borehole material from western Belarus (Melnikova, personal observation; herein Pl. 4, fig. 8). In the Asiatic part of the former Soviet Union late Cambrian faunas are documented mostly from Kazakhstan and Gorny Altay (Figs 1-3).

Several apparently short-ranging new species, including beyrichonids, are known from the late Cambrian of Maly Karatau of southern Kazakhstan (Melnikova \& Taylor manuscript; herein Pl. 4, figs 1, 2, 6, 9-11). In central Kazakhstan
Anabarochilina konevae Melnikova, 1990 is known from sediments of unspecified late Cambrian age and Monasterium ivshini Melnikova, 1990, Monasterium (= gen. nov.?) seletiensis Melnikova, 1990 and an undetermined phosphatocopid (= Dielymella sp. of Melnikova, 1990) occur in deposits of Aksayan age (Melnikova, 1990a). Monasterium ivshini thus extends the known range of the genus into the late Cambrian (the Chinese Monasterium bucerum Zhang, 1987 is early Cambrian and Australian species of Monasterium are middle Cambrian; see Zhang, 1987; Fleming, 1973; Hinz, 1992).

In Gorny Altay the upper (Saksian Stage) part of the Tandoshka Formation has yielded Altajanella costulata Melnikova, 1992 and Uskutchiella sulcata Melnikova, 1992.

\section{BIOGEOGRAPHIC SIGNIFICANCE}

In the Cambrian the Siberian and Estonian/western Russian areas of the former Soviet Union were positioned on the palaeocontinents of Siberia and Baltica, respectively (Fig. 4). Siberia lay at southerly tropical latitudes and Baltica at about $60^{\circ}$ south, within the Bigotinid and Olenellid trilobite faunal realms, respectively (see Scotese \& Mckerrow, 1990; Mckerrow et al., 1992). The sparse bradoriid and phosphatocopid faunas of Estonia and western Russia show some affinities with assemblages from Scandinavia (Baltica) and New Brunswick/Nova Scotia of the Canadian maritimes (situated on Avalonia, a southerly high latitude microcontinent on the northern margin of the Gondwana palaeocontinent). Those of Siberia show affinities particularly with South China, which in the Cambrian was an equatorial continental block on the northeastern margin of Gondwana.

Kazakhstan was once considered to be a discrete continental block or part of the Siberian plate (e.g. Scotese et al., 1979; Scotese \& Mckerrow, 1990) but it is now thought to be an amalgamation of terranes, many of which may be seperated by ophiolites (Mckerrow et al., 1992). This so-called Altaid tectonic collage, which also includes Kirghizia and Gorny Altay, may have evolved dominantly along a subduction zone which, during the Cambrian, developed along the margin of a unified 'BalticaSiberia' continent (Sengör et al., 1993). Early Palaeozoic faunas from different parts of Kazakhstan show affinities with Siberia, China and Europe (see summary in McKerrow et al., 1992, p. 603).

\section{Estonia and western Russia}

Early Cambrian bradoriid and phosphatocopid faunas of Baltica are poorly known (e.g. see Wiman, 1905; Hinz-

\section{Explanation of Plate 2}

Early (figs 2-11) and middle Cambrian (fig. 1) bradoriids/phosphatocopids of the former Soviet Union. All valves are figured in lateral view. figs 4, 7 are scanning electron micrographs; all other figures are light photographs (methods of Siveter, 1990). fig. 1, Amgan, Malaya-Kuonamka River, Siberia. figs 2, 5, Botomian, Argaa-Salaa River, Lena-Aldan region, Siberia. fig. 3, Sinsk Formation (Botomian; Bergeroniellus gurarii Biozone), right bank of the Lena River, $1 \mathrm{~km}$ from Sinsk, Siberia. figs 4, 7-11, Bystraya Formation (Botomian), watershed between Ernichnaya and Uslop valleys, Georgievka, E Trans-Baikal Region. fig. 6, Siberia: exact locality and horizon unknown. figs 1, 2, 5. Leperditia? concentrisulcata Abushik, 1960 (= gen. nov.). fig. 1, holotype, right valve, PIN N4342/65, length $7.14 \mathrm{~mm}$. fig. 2, left valve, PIN N4342/80, length $4.05 \mathrm{~mm}$. fig. 5, left valve (stereopair), PIN N4342/81, length $4.19 \mathrm{~mm}$. fig. 3. Bradoria ordinata Melnikova, 1983 (=gen. nov.). Holotype, left valve (stereo-pair), PIN N3465/11, length $6.66 \mathrm{~mm}$. fig. 4. Walcottella? sp. of Melnikova, 1988. Right? valve, PIN N4372/47, length $1 \mathrm{~mm}$. fig. 6. Kunmingella sp. Right valve, PIN N4342/70, length $5.48 \mathrm{~mm}$. fig. 7. Liangshanella? sayutinae (Melnikova, 1988). Holotype, right valve, PIN N4342/48, length $1.38 \mathrm{~mm}$. figs 8, 9. Alutella usloniensis (Melnikova, 1988). fig. 8, right valve, PIN N4342/54, length $3.81 \mathrm{~mm}$; fig. 9, holotype right valve, PIN N4342/55, length 4.19 mm. figs 10, 11. Sunella parva Melnikova, 1988 (gen, nov.?). Holotype, carapace, PIN N4342/40, right (fig. 10) and left (fig. 11) lateral views, length $1.90 \mathrm{~mm}$. 


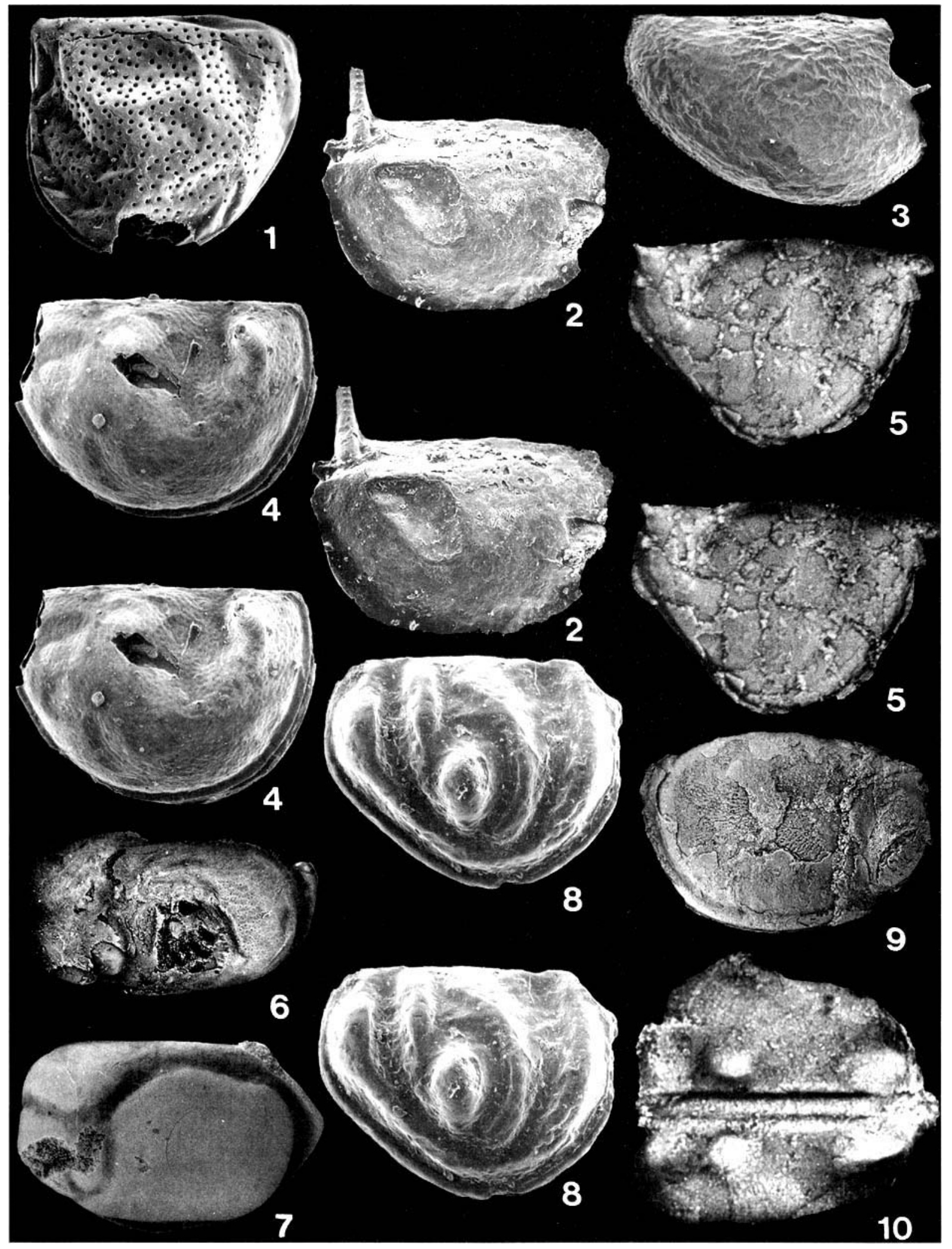


Schallreuter, 1993c). Those of western Russia and Estonia show links with Avalonian and Baltica faunal elements. Beyrichona Matthew, 1886 occurs in the late? Cambrian of Belarus and is also a characteristic component of the Cambrian bradoriid faunas of the Avalonian early and middle Cambrian of eastern Canada and middle Cambrian and early Ordovician of southern Britain (Matthew, 1886; Siveter \& Williams, 1997; Williams \& Siveter, in press). The Estonian 'Bradoria' estonica may be congeneric with species from early Cambrian erratic boulders in Schleswig-Holstein, North Germany (see Hinz-Schallreuter, 1993c, figs 16, 17). The poorly known, early Cambrian Konicekion Snajdr, 1975 from Estonia bears some resemblance to the widespread Albrunnicola Martinsson, 1979, a genus found in other Baltica and also Gondwanan and Chinese localities (see Hinz-Schallreuter, 1993c). The middle Cambrian Vojbokalina is endemic, being known only from the Leningrad region.

\section{Siberia}

The early Cambrian bradoriid and phosphatocopid faunas of eastern Siberia are dominated by cambriids, a palaeogeographically widespread group, which span parts of the Redlichiid, Bigotinid and Olenellid trilobite realms, but which were apparently restricted to within tropical/subtropical regions. This suggests possible distributional control by palaeo-latitudinal factors such as temperature (Siveter et al., 1994 and references therein). The Siberian bradoriid Cambria Neckaja \& Ivanova, 1956 is also probably a common element of south Chinese Cambrian faunas (the full biogeographic significance of cambriid species awaits revision of Chinese material such as that of Huo et al., 1991). The presence of Kunmingella confirms this affinity with the Chinese faunas.

The middle and late Cambrian faunas of Siberia include the cosmopolitan Anabarochilina and a vestrogothiid species. Vestrogothids are more typical of the middle and late Cambrian faunas of Scandinavia (Baltica) and southern Britain (Avalonia).

\section{Kazakhstan, Kirghizia and Gorny Altay}

The bradoriid and phosphatocopid faunas of central and southern Kazakhstan and possibly Kirghizia suggest a faunal affinity with China and probably Australia, an area synonymous with the Cambrian Redlichiid trilobite realm. Early Cambrian bradoriid and phosphatocopid faunas from northeastern central Kazakhstan include Alutella, Tsunyiella and a possible cambriid species; southern Kazakhstan (Maly Karatau) and Kirghizia yield Dabashanella retroswinga (see Melnikova, 1990a, 1990b). This fauna is very similar to those of contemporaneous deposits in the Tarim and southern (Yangtze Platform) areas of China (see Zhang, 1987; Huo \& Cui, 1989; Huo et al., 1991 and references therein). Middle and late Cambrian forms from Maly Karatau, detailed study of which is in preparation (Melnikova \& Taylor), includes Monasterium and an Anabarochilina species with affinities to the Australian $A$. australis Hinz-Schallreuter (Pl. 3, fig. 9).

The bradoriid and phosphatocopid faunas of the Eastern Trans-Baikal region, such as Liangshanella? and Alutella, show obvious affinities with faunas from China (Redlichiid trilobite realm). Ushkarella and Altajanella appear to be endemic to Kazakhstan and Gorny Altay, respectively.

\section{COLLECTIONS}

Nearly all bradoriid and phosphatocopid material from the former Soviet Union is housed in the Palaeontological Museum of the Palaeontological Institute (PIN) of the Russian Academy of Sciences, Moscow, Russia. The collections include material from Estonia, Belarus, the Leningrad Region, Siberia, Kazakhstan, Kirghizia and the Gorny Altay-Mongolian belt and are registered under the prefixes N1117, N2175, N3465, N4341-4344 and N4346.

The Geological Museum of the Institute of Geological Sciences, Alma-Ata, Kazakhstan, houses the small type collection of Ushkarella specimens, registered under N2348. The phosphatocopids from the Kuonamka Formation (Müller et al., 1995) are housed at the Institute of Palaeontology, University of Bonn, Germany.

\section{CONCLUSIONS}

From this review we conclude that the Cambrian Bradoriida and Phosphatocopida of the former Soviet Union:

- comprise about 40 species but material is relatively rare, consisting of only about 250 specimens;

- have been recovered mostly as crack-out material from clastic and impure carbonate rocks; acid resistant valves recovered from limestones are a minor component of the known fauna; - occur chiefly in Asia (Kirghizia and especially Siberia and Kazakhstan); only sparse faunas are known from west of the Urals (Leningrad region, Belarus and Estonia);

\section{Explanation of Plate 3}

Middle (figs 1, 5, 8-10) and late (figs 2-4, 6, 7) Cambrian bradoriids/phosphatocopids of the former Soviet Union. fig. 10 is a dorsal view; all others are lateral views. figs 5-7,9, 10 are light photographs (methods of Siveter, 1990); all other figures are scanning electron micrographs. figs 1, 5, 9, Mayan (Lejopyge trilobite Biozone), Kyr-Shabakty section, Maly Karatau, S Kazakhstan. fig. 2, Lermontov Horizon (Aksayan), right bank of the Selety River, $11 \mathrm{~km}$ E of Bestyube, Kazakhstan. figs 3, 4, Shiderty Horizon (Aksayan), right bank of the Olenty River, Kazakhstan. fig. 6, Edrei Beds (Aksayan), Agyrek Mountains, Kazakhstan. fig. 7, Ayusokkanian, vicinity of the River Kotui, Siberia. fig. 8, Sablinka Formation (Mayan), Saryia River, $800 \mathrm{~m}$ from Vojbokalo, Leningrad Region, Russia. Fig. 10, Sekten Formation (Amgan), left bank of the Lena River, $4 \mathrm{~km}$ from Chekurovka, Siberia. fig. 1. Euzepaera? sp. nov. Left valve, PIN N4343/46, length $0.71 \mathrm{~mm}$. fig. 2. Monasterium seletiensis Melnikova, 1990 (=gen. nov.?). Right valve (stereo-pair), PIN N4343/60, length $0.71 \mathrm{~mm}$. fig. 3. 'Dielymella' sp. of Melnikova, 1990. Right valve, PIN N4343/28, length $1 \mathrm{~mm}$. fig. 4. Monasterium ivshini Melnikova, 1990. Holotype, right valve (stereo-pair), PIN N4343/17, length 0.81mm. fig. 5. Beyrichona sp. nov. A. Left valve (stereo-pair), PIN N4343/57, length $1.90 \mathrm{~mm}$. fig. 6. Anabarochilina konevae Melnikova, 1990. Holotype, left valve, PIN N4343/1, length 5.71 mm. fig. 7. Anabarochilina primordialis (Linnarsson, 1869). Left valve, PIN N4342/60, length $8 \mathrm{~mm}$ (measurement revised from Siveter et al., 1993). fig. 8. Vojbokalina magnifica Melnikova, 1984. Holotype, carapace, PIN N4341/6, left lateral view (stereo-pair), length $1.37 \mathrm{~mm}$. fig. 9. Anabarochilina sp. Right valve, PIN N4343/55, length $8 \mathrm{~mm}$. fig. 10. Vestrogothia? sp. Incomplete carapace, PIN N4342/100, length $2.57 \mathrm{~mm}$. 


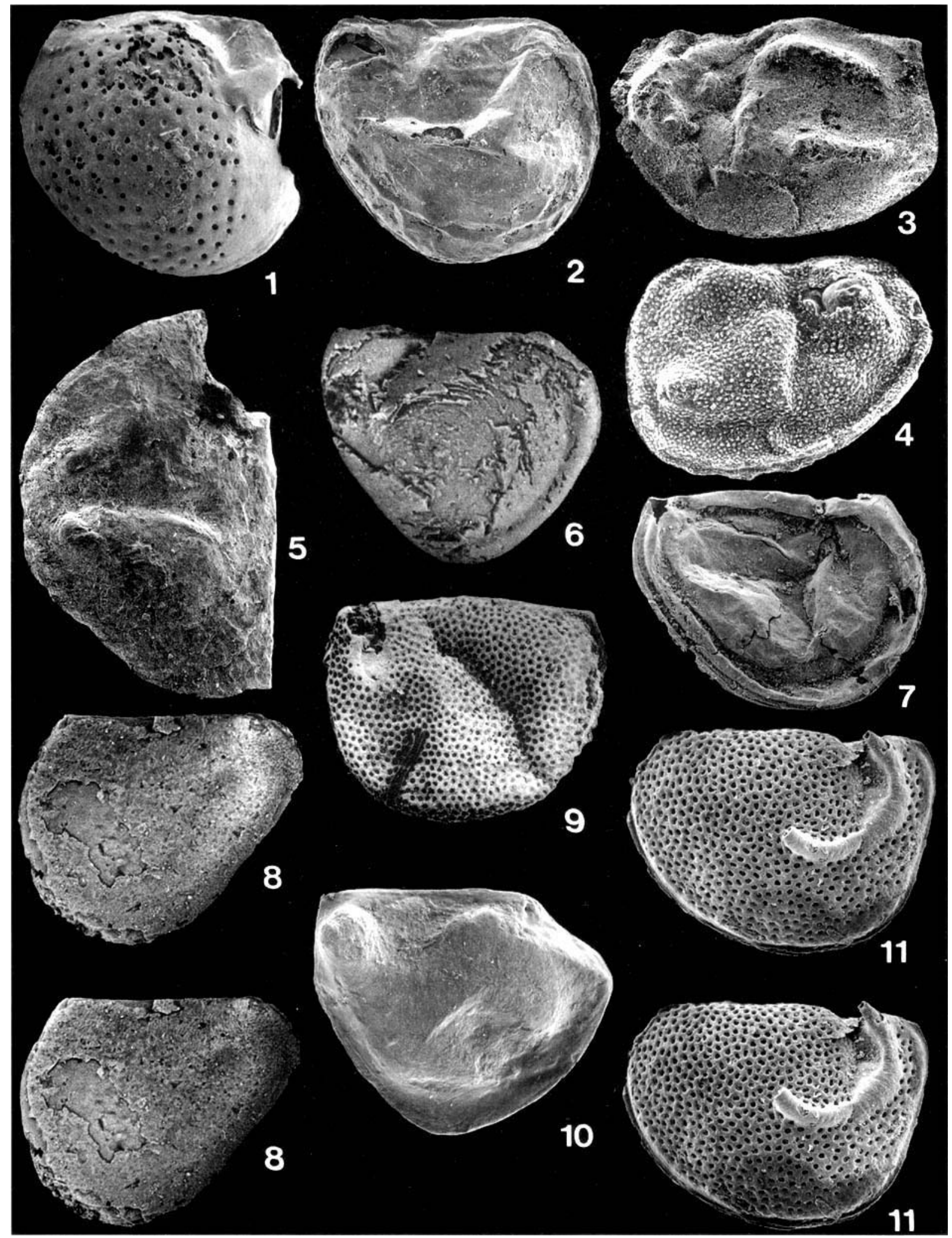




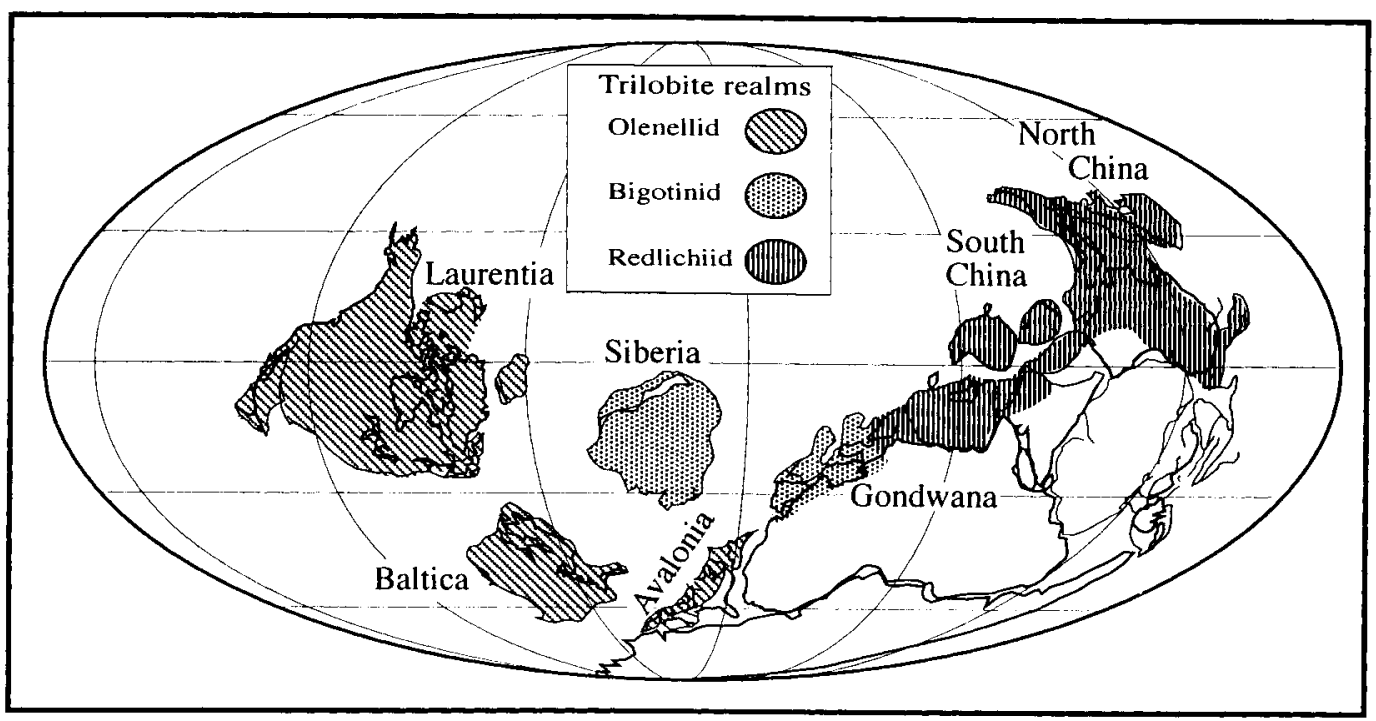

Fig. 4. Early Cambrian palaeogeography and associated trilobite realms (after McKerrow et al., 1992).

- are predominantly of early Cambrian age; middle and late Cambrian faunas are scarcer and known largely from Siberia and Kazakhstan;

- include many short-ranging species, a few of which have practical international correlative value but most of which currently have only local biostratigraphic significance;

- west of the Urals show faunal links with those of the early Palaeozoic Baltica and Avalonia palaeocontinents (Olenellid trilobite realm); those of Siberia, and central Asia have links with faunas of palaeocontinental South China and eastern Gondwana (Redlichiid trilobite realm).

A formal systematic and monographic treatment of the Bradoriida and Phosphatocopida of the former Soviet Union ideally requires much more material than is currently available. In particular, the use of acid preparation techniques on limestones should be targeted as a potential high yield mode of recovery of valves, and as a possible source of specimens with soft-part preservation. Such studies would facilitate enhanced evaluation of the taxonomic, biostratigraphic and biogeographic significance of the faunas.

\section{ACKNOWLEDGEMENTS}

We thank the Natural Environment Research Council of Great Britain for supporting this research (Grant GR3/8655); A. Yu. Rozanov (Palaeontological Institute, Academy of Sciences, Moscow), A.W.A. Rushton (British Geological Survey) and Hou Xianguang (Academia Sinica, Nanjing) for reading the manuscript; and Anna Abushik (All-Russian Geological Research Institute, St. Petersburg) and Zhang Shunxin (China University of Geosciences, Beijing) for access to Russian and Chinese literature. LMM and DIS gratefully acknowledge study visit facilities provided at the Department of Geology, University of Leicester and the Palaeontological Institute, Academy of Sciences, Moscow, respectively.

\section{Manuscript received December 1995 Manuscript accepted July 1996}

Explanation of Plate 4

Late Cambrian bradoriids/phosphatocopids of the former Soviet Union (figs 1-11). fig. 5 is a dorsal view; all others are lateral views. figs 6, 8, are light photographs (methods of Siveter, 1990); all other figures are scanning electron micrographs. figs 1, 6, 9-11, Saksian (Ivshinagnostus ivshini Biozone), Kyr-Shabakty section, Maly Karatau, S Kazakhstan. fig. 2, Aksayan (Eurudagnostus ovaliformis Biozone), Kyr-Shabakty section, Maly Karatau, S Kazakhstan. figs 3-5, Tandoshka Formation (Saksian), left bank of the Uskutch River, $3 \mathrm{~km}$ from its confluence with the Bol'shaya-Isha River, Gorny Altay. fig. 7, Lermontov Horizon (Aksayan), right bank of the Selety River, $11 \mathrm{~km}$ E of Bestyube, Kazakhstan. fig. 8, Borehole 'Brest1', Belarus; depth between 903.6 and $905 \mathrm{~m}$ (exact horizon unknown). fig. 1. Euzepaera? sp. nov. Right valve, PIN N4343/47, length 0.62 mm. fig. 2. Bradoriid sp. Left valve, PIN N4343/49, length $1.48 \mathrm{~mm}$. figs 3, 4. Altajanella costulata Melnikova, 1992. fig. 3, Holotype, left valve, PIN N4346/1, length $1.19 \mathrm{~mm}$. fig. 4, silicone rubber cast of right valve (PIN N4346/10), length $1.19 \mathrm{~mm}$. fig. 5. Uskutchiella sulcata Melnikova, 1992. Holotype, incomplete open carapace, PIN N4346/25, length $0.94 \mathrm{~mm}$. fig. 6. Beyrichona? sp. C. Left valve, PIN N4343/58, length $2.86 \mathrm{~mm}$. fig. 7 . Bradoria sp. B. of Melnikova, 1990 (=Liangshanella?). Carapace, PIN N4343/31, left lateral view, length $1.05 \mathrm{~mm}$. fig. 8. Beyrichona sp. B. Carapace, PIN N4341/ 101 , right lateral view, length $2.57 \mathrm{~mm}$. fig. 9. Gen. et sp. nov. left valve, PIN N4343/48, length $1.00 \mathrm{~mm}$. fig. 10. Beyrichona? sp. nov. D. Carapace, PIN N4343/43, right lateral view, length $2.29 \mathrm{~mm}$. fig. 11. Monasterium sp. nov. Incomplete carapace, PIN N4343/51, right lateral view (stereo-pair), length $1 \mathrm{~mm}$. 


\section{REFERENCES}

Abushik, A. F. 1960. First discovery of leperditaceans from the Cambrian of the Siberian Platform. Vestnik Leningradskogo Universitet, seriya geologii i geografii, 6: 93-98. [In Russian].

Astashkin, V. A., Pegel, T. V., Shabanov, Yu. Ya., Sukhov, S. S., Sundukov, V. M., Repina, L. N., Rozanov, A. Yu. \& Zhuravlev, A. Yu. 1991. The Cambrian System on the Siberian Platform correlation chart and explanatory notes. International Union of Geological Sciences, Publication No. 27, 133 pp.

Astashkin, V. A., Belyaeva, G. V., Esakova, N. V., Osadchaya, D. V., Pakhomov, N. N., Pegel, T. V., Repina, L. N., Rozanov, A. Yu. \& Zhuravlev, A. Yu. 1995. The Cambrian System of the fold-belts of Russia and Mongolia-correlation chart and explanatory notes. International Union of Geological Sciences, Publication No. 32, 132 pp.

Brasier, M. D. 1989. China and the Palaeotethyan Belt (India, Pakistan, Iran, Kazakhstan, and Mongolia), 41-74. In Cowie, J. W. \& Brasier, M. D. (Eds) The Precambrian-Cambrian Boundary. Oxford Monographs on Geology and Geophysics, 12. Clarendon Press, Oxford.

Briggs, D. E. G. 1983. Affinities and early evolution of the Crustacea: the evidence of the Cambrian fossils, 1-22. In Schram, F. R. (Ed.) Crustacean phylogeny. A. A. Balkema, Rotterdam.

Cowie, J. W. 1989. Siberia and eastern Europe. 75-82. In Cowie, J. W. \& Brasier, M. D. (Eds) The Precambrian-Cambrian Boundary. Oxford Monographs on Geology and Geophysics, 12. Clarendon Press, Oxford.

Ergaliev, G. K. 1980. The Middle and Upper Cambrian Trilobites from Maly Karatau. 'Nauka', Alma-Ata, Kazakhstan SSR, 211 pp. [In Russian].

Fleming, P. J. G. 1973. Bradoriids from the Xystridura Zone of the Georgina Basin, Queensland. Publications, Geological Survey of Queensland, 356: 1-9.

Hinz, I. C. U. 1992. On Monasterium oepiki Fleming. A Stereo-Atlas of Ostracod Shells, 19: 123-130.

Hinz-Schallreuter, I. 1993a. Ostracodes from the middle Cambrian of Australia. Neues Jahrbuch für Geologie und Paläontologie, Abhandlungen, 188: 305-326.

Hinz-Schallreuter, 1. 1993b. Ein mittelkambrischer hesslandonider Ostrakod sowie zur Morphologie und systematischen Stellung der Archaeocopa. Archiv für Geschiebekunde, 1: 329-350.

Hinz-Schallreuter, I. 1993c. Cambrian ostracodes mainly from Baltoscandia and Morocco. Archiv für Geschiebekunde, 1: 385-448.

Hinz-Schallreuter, I. \& Jones, P. J. 1994. Gladioscutum lauriei $\mathrm{n}$. gen. n. sp. (Archaeocopida) from the middle Cambrian of the Georgina Basin, central Australia. Paläontologische Zeitschrift, 68: 361-375.

Hou, Xianguang \& Bergström, J. 1991. The arthropods of the Lower Cambrian Chengilang fauna, with relationships and evolutionary significance, 179-187. In Simonetta, A. \& Conway Morris, S. (Eds) The Early Evolution and the Significance of Problematic Taxa. Cambridge University Press, Cambridge.

Hou, Xianguang, Siveter, David J., Williams, M., Walossek, D. \& Bergström, J. Appendages of the arthropod Kunmingella from the early Cambrian of China: its bearing on the systematic position of the Bradoriida and the fossil record of the Ostracoda. Philosophical Transactions of the Royal Society, Series B, 351: 1131-1145

Huo, Shicheng. 1956. Brief notes on lower Cambrian Archaeostraca from Shensi and Yunnan. Acta Palaeontologica Sinica, 4: 425-445. [In Chinese with English Abstract].

Huo, Shicheng \& Cui, Zhilin. 1989. On the ages of the Tsunyiellidbearing strata in China. Geological Review, 35: 72-83. Beijing. [In Chinese with English Abstract].

Huo, Shicheng, Shu, Degan \& Cui, Zhilin. 1991. Cambrian Bradoriida of China. Geological Publishing House, Beijing, 249 pp. [In Chinese with English Summary].

Huo, Shicheng, Shu, Degan, Zhang, Xiguang, Cui, Zhilin \& Tong, Haowen 1983. Notes on Cambrian bradoriids from Shaanxi, Yunnan, Sichuan, Guizhuo, Hubei and Guangdong. Journal of Northwest University, 13: 56-75. [In Chinese with English Abstract]

Ivanova, V. A. 1964. New species of Bradoriida (Ostracodoidea) from the Aldanian Stage of the Khara-Ulakh Mountains. Paleontologicheskii Zhurnal, 1964: 111-113. [In Russian].

Jones, P. J. \& McKenzie, K. G. 1980 . Queensland middle Cambrian
Bradoriida (Crustacea): new taxa, palaeobiogeography and biological affinities. Alcheringa, 4: 203-225.

Kobayashi, T. \& Kato, F. 1951. On the ontogeny and the ventral morphology of Redlichia chinensis with description of Alutella nakamurai new gen. and sp. Journal of the Faculty of Science, University of Tokyo, section 2, 8: 85-90.

Koneva, S. P. 1978. The first ostracode find in the Lower Cambrian of Kazakhstan. Paleontologicheskii Zhurnal, 1978: 150-152. [In Russian]

Linnarsson, J. G. O. 1869. Om Vestergötlands Cambriska och Siluriska Aflagrigar. Kongliga Svenska Vetenskaps-Akademiens Handlingar, 8: $1-89$.

Malz, H. 1990. Nomenclatorial annotations on "Cambrian and early Ordovician "Ostracoda" (Bradoriida) in China' by Shu, 1990. Courier Forschungs-Institut Senckenberg, 123: 331-332.

Mambetov, A. M. \& Repina, L. N. 1979. The Lower Cambrian of Talass Ala-Too and its correlation with sections of Maly Karatau and the Siberian Platform, 93-138. In Zhuravleva, I. T. \& Meshkova, N. P. (Eds) Biostratigraphy and Palaeontology of the Lower Cambrian of Siberia. 'Nauka', Novosibirsk. [In Russian]

Martinsson, A. 1979. Albrunnicola, a new name for the Cambrian ostracode genus Longispina Andres, 1969. Lethaia, 12: 27.

Matthew, G. F. 1886. Illustrations of the fauna of the St. John Group continued. No. 3: Descriptions of new genera and species. Proceedings and Transactions of the Royal Society of Canada, Series 1, 3 (for 1885): 29-84.

McKerrow, W. S., Scotese, C. R. \& Brasier, M. D. 1992. Early Cambrian continental reconstructions. Journal of the Geological Society, London, 149: 599-606.

Melnikova, L. M. 1983a. Order Bradoriida Raymond, 1935. In Grigorieva, N. V., Melnikova, L. M. \& Pelman, Yu. L. Brachiopods, Ostracods (Bradoriida) and small shelly fossils from the stratotype Region of the Lower Cambrian Stages. Paleontologicheskii Zhurnal, 1983: 54-58. [In Russian].

Melnikova, L. M. 1983b. Class Crustacea, Order Bradoriida. In Rozanov, A. Yu. \& Sokolov, B.S. (Eds) Lower Cambrian Stage Subdivision of Siberia. Atlas of Fossils. Transactions of the Institute of Geology and Geophysics, 558: 145-146. Moscow, Nauka. [In Russian]

Melnikova, L. M. 1984. In Khazanovich, K. K., Popov, L. E. \& Melnikova, L. M. Inarticulate brachiopods, ostracods (Bradoriida) and hiolithelmintes from the Sablinka Formation of the Leningrad Region. Paleontologicheskii Zhurnal 1984: 33-47. [In Russian].

Melnikova, L. M. 1985. New name for Lower Paleozoic Ostracods. Paleontologicheskii Zhurnal, 1985: 110. [In Russian].

Melnikova, L. M. 1987. Some bradoriids (Ostracoda) from the Tiskre Formation (Lower Cambrian) of Northern Estonia. Paleontologiches kii Zhurnal, 1987: 128-131. [In Russian].

Melnikova, L. M. 1988. Some Bradoriids (Crustacea) from the Botomian Stage of the East Trans-Baikal Region. Paleontologicheskii Zhurnal, 1988: 114-117. [In Russian].

Melnikova, L. M. 1990a. Early- and Late Cambrian Bradoriida (ostracods) from North-Eastern Central Kazakhstan. 170-176. In Repina, L. N. (Ed.) Cambrian Biostratigraphy and Palaeontology of Northern Asia. Transactions of the Institute of Geology and Geophysics, 765. 'Nauka', Siberian Branch, Novosibirsk. [In Russian].

Melnikova, L. M. 1990b. In Melnikova, L. M. \& Mambetov, A. M (Eds) Lower Cambrian ostracods from North Tien-Shan. Paleontologicheskii Zhurnal, 1990: 57-61. [In Russian].

Melnikova, L. M. 1990c. Cambrian Bradoriids of the USSR. Abstracts, 3rd International Cambrian Symposium, Novosibirsk.

Melnikova, L. M. 1990d. Cambrian Ostracodes. In Abushik, A. F. et al. (Eds) Practical Manual on Microfauna of USSR. 4, Paleozoic Ostracoda. Ministry of Geology of USSR, All-Union Geological Research Institute, L. Nedra, 356 pp. [In Russian].

Melnikova, L. M. 1992. The first late Cambrian bradoriids (Ostracoda) from Gorny Altay. Paleontologicheskii Zhurnal, 1992: 80-82. [In Russian].

Mens, K., Bergström, J, \& Lendzion, K. 1990. The Cambrian System on the East European Platform - correlation chart and explanatory notes. International Union of Geological Sciences, Publication No. $25,73 \mathrm{pp}$.

Müller, K. J. 1964. Ostracoda (Bradorina) mit phosphatischen Gehäusen aus dem oberkambrium von Schweden. Neues Jahrbuch für Geologie 
und Palöontologie, Abhandlungen, 121: 1-46.

Müller, K. J. 1979. Phosphatocopine ostracodes with preserved appendages from the Cambrian of Sweden. Lethaia, 12: 1-27.

Müller, K. J. 1982. Hesslandona unisulcata sp. nov. with phosphatized appendages from upper Cambrian 'orsten' of Sweden, 276-307. In Bate, R. H., Robinson, E. \& Sheppard, L. M. (Eds) Fossil and Recent Ostracoda. Ellis Horwood, Chichester.

Müller, K. J. \& Walossek, D. 1991. Ein Blick durch das Orsten-Fenster in die Arthropodenwelt vor 500 Millionen Jahren. Verhandlungen der Deutschen Zoologischen Gesellschaft, 84: 281-294.

Müller, K. J., Walossek, D. \& Zakharov, A. 1995. 'Orsten' type phosphatized soft-integument preservation and a new record from the Middle Cambrian Kuonamka Formation in Siberia. Neues Jahrbuch für Geologie und Palöontologie, Abhandlungen, 197: 101-118.

Neckaja, A. I. \& Ivanova, V. A. 1956. The first ostracode find in the Lower Cambrian of East Siberia. Doklady Akademii Nauk SSSR, 111: 1095-1097. [In Russian].

Raymond, P. E. 1935. Leonchoila and other mid-Cambrian Arthropoda. Bulletin of the Museum of Comparative Zoology, 76: 205-230.

Rushton, A. W. A., Siveter, D. J. \& Williams, M. In press. The Cambrian. In Athersuch, J., Keen, M. \& Wilkinson, I. P. (Eds) $A$ Stratigraphical Index of British Ostracoda (2nd edn). British Micropalaeontological Society.

Scotese, C. R. \& McKerrow, W. S. 1990. Revised world maps and introduction. In McKerrow, W. S. \& Scotese, C. R. (Eds) Palaeozoic Palaeogeography and Biogeography. Memoir of the Geological Society of London, 12: 1-21.

Scotese, C. R., Bambach, R. K., Barton, C., Van der Voo, R. \& Ziegler, A. M. 1979. Paleozoic base maps. Journal of Geology, 87: 217-227.

Sengör, A. M. C., Natal'in, B. A. \& Burtman, V. S. 1993. Evolution of the Altaid tectonic collage and Palaeozoic crustal growth in Eurasia. Nature, 364: 299-307.

Shu, Degan. 1990a. Cambrian and lower Ordovician Bradoriida from Zhejiang, Hunan and Shaanxi provinces. Northwest University Press, Xian, $95 \mathrm{pp}$. [In Chinese with English Summary].

Shu, Degan. 1990b. Cambrian and early Ordovician "Ostracoda" (Bradoriida) in China. Courier Forschungs-Institut Senckenberg, 123: 315-330.

Siveter, David J. \& Williams, M. 1995. An early Cambrian assignment for the Caerfai Group of South Wales. Journal of the Geological Society, 152: 221-224.
Siveter, David J. \& Williams, M. 1997. Cambrian bradoriid and phosphatocopid arthropods of North America. Special Papers in Palaeontology

Siveter, David J., Williams, M., Abushik, A.F., Berg-Madsen, V. \& Melnikova, L. 1993. On Anabarochilina primordialis (Linnarsson). A Stereo-Atlas of Ostracod Shells, 20: 71-76.

Siveter, David J., Williams, M., Hinz-Schallreuter, I. \& Melnikova, L. 1994. On Cambria melnikovae Ivanova. A Stereo-Atlas of Ostracod Shells, 21: 13-16.

Siveter, David J., Williams, M., Peel, J. S. \& Siveter, D. J. 1996. Bradoriida (Arthropoda) from the early Cambrian of North Greenland. Transactions of the Royal Society of Edinburgh: Earth Sciences, 86 (for 1995), 113-121.

Siveter, D. J. 1990. Photography. 505-508. In Briggs, D. E. G. \& Crowther, P. R. (Eds) Palaeobiology: A Synthesis. Blackwell, Oxford.

Snajdr, M. 1975. Konicekion nov. gen. from the middle Cambrian of Bohemia (Ostracoda). Vestnik Ustredniho ustavu geologickeho, 50: 153-156.

Walossek, D. \& Müller, K. J. 1992. The 'Alum Shale Window' contribution of 'Orsten' arthropods to the Phylogeny of Crustacea. Acta Zoologica (Stockholm), 73: 305-312.

Williams, M. \& Siveter, David J. In press. British Cambrian and Tremadoc Bradoriida and Phosphatocopida. Monograph of the Palaeontographical Society.

Williams, M., Siveter, David J., Hinz-Schallreuter, I. \& Melnikova, L. 1994a. On Cambria sibirica Neckaja \& Ivanova. A Stereo-Atlas of Ostracod Shells, 21: 9-12.

Williams, M., Siveter, David J., Rushton, A. W. A. \& Berg-Madsen, V. 1994b. The Upper Cambrian bradoriid ostracod Cyclotron lapworthi is a hesslandonid. Transactions of the Royal Society of Edinburgh: Earth Sciences, 85: 123-130.

Wiman. C. 1905. Studien über das Nordbaltische Silurgebiet. I. Olenellussandstein, Obolussandstein und Ceratopygeschiefer. Bulletin of the Geological Institution of the University of Uppsala, 6: 36-76.

Zhang, Xiguang. 1987. Moult stages and dimorphism of Early Cambrian bradoriids from Xichuan, Henan, China. Alcheringa, 11: 1-19.

Zhang, W. 1974. Bradoriida, 107-111. In Nanjing Institute of Geology and Palaeontology (Ed.) Handbook of Stratigraphy and Palaeontology of Southwest China. Science Press, Beijing.

Zhao, Yuhong \& Tong, Haowen. 1989. On Dabashanella retroswinga Huo, Shu and Fu. A Stereo-Atlas of Ostracod Shells, 16: 13-16. 